\title{
From Coast to Coast: The Mapping of the Adriatic Sea by the Joint Forces of the Austro-Hungarian and Italian Hydrographic Offices
}

\author{
Mirela Altić \\ Institute of Social Sciences, Zagreb, Croatia, email: mirela.altic@gmail.com
}

Keywords: History of Cartography, 19th Century, Adriatic Sea, Hydrographic Survey, Austrian Cartography, Italian Cartography

\begin{abstract}
:
With the establishment of the second Austrian rule on the eastern Adriatic coast (1815), after several centuries, the Adriatic Sea was divided between two sides - Italian (Papal States and Kingdom of Two Sicilies) which ruled the western Adriatic coast, and the Austrian, which ruled the eastern coast and Lombardy-Venetia. Such division of the Adriatic Sea between the two powers in constant tension adversely affected the dynamics of mapping, and in the mid19th century, there was a serious setback in mapping. In the 1860s, the strengthening of Italian and Austrian realms (Italy began its unification in 1860, and the Austrian Empire was converted into the Austro-Hungarian Monarchy in 1867) created a need for cooperation between the two empires on the joint mapping of the Adriatic Sea, which was to enable the production of modern charts based on a comprehensive survey covering the whole sea surface area, from coast to coast.
\end{abstract}

For the purposes of the hydrographic survey, both imperial powers established their hydrographic offices as part of their military (naval) forces. The Austrian Empire established its Hydrographic Office in 1860, at first in Trieste and, from 1869 onwards, in the city of Pula (Hydrographisches Amt der k. u. k. Kriegsmarine). Its Italian counterpart, the Istituto idrografico della Marina, was founded in 1872 with its headquarters in Genoa (yet its first administrative act appeared as early as 1867). A systematic survey of the Adriatic Sea was started on its eastern side by the Austrian Hydrographic Office. It was conducted from 1866 to 1870 under the supervision of the experienced mariner and hydrographer Tobias Ritter von Oesterreicher. After land and sea surveys had been carried out on the basis of a dense triangulation network (first-, second-, and third-order triangulation), the first edition of the hydrographic charts of the eastern Adriatic coast was prepared by the Military Geographical Institute in Vienna and published by W. Essmann in Trieste as early as 1870 (and reissued in 1872). The survey resulted in a general chart of the Adriatic at a scale of 1:1000 000, four course charts of the whole Adriatic Sea at a scale of 1:350 000, thirty-one coastal charts of the eastern Adriatic at scales of 1:40 000 to 1:100 000, and fifty-seven harbour charts at scales of 1:20 000 to 1:30 000. The survey of the Italian side of the Adriatic was conducted under the supervision of Counter-Admiral Duke Antonio Imbert, who earlier assisted Oesterreicher in the survey of the eastern coast. It started in 1867 and, by the end of 1873, conducted by the joint forces of the Austro-Hungarian and Italian hydrographic offices, resulted in a series of twenty-four charts at a scale of 1:100 000. Printed by the Military Geographical Institute in Vienna in 1873, together with a series covering the eastern Adriatic coast, these charts continued to serve as the main base map in the Office's cartographic production for several decades, but also as a template for maps of Adriatic issued by foreign hydrographic offices, including that of the British Admiralty.

The collaboration between the Austrian and Italian hydrographic offices continued, jointly promoting the improvement of quality of nautical charts of the Adriatic and the development of the hydrographic service in general. Apart from producing the first modern charts of the Adriatic, this survey marked the beginning of a state institutions for hydrographic exploration, including first measurements of geomagnetism, salinity, currents, and tides. The 19th-century charting thus played a crucial role in the birth of the official hydrographic services and the development of modern hydrographic exploration of the Adriatic. The proposed paper is based on archival sources. 